\title{
北陸先端科学技術大学院大学 マテリアルサイエンス研究科 金子研究室
}

\section{1.はじめに}

北陸先端科学技術大学院大学 (通称「JAIST」または「ほ くせん」）は 16 年前に設立された本国初の大学院大学であ る. 当時, 大学院だけの大学ということで非常に珍しく, 東京にいた筆者の周りでもかなりの噂となったことを覚え ている. 大学院レベルの教育と研究を行う大学であり, そ のレベルもかなり高い. 本学の状況は本誌の昨年第 5 号1) に紹介されたばかりであるので, 詳しい紹介は本報では割 愛させていただく.入学する学生のバックグラウンドは千 差万別であり, 研究室一つ一つをとっても非常にユニーク なクラスターとなっている，筆者は本学に着任してからま だ半年ほどしか経っていないが，着任後まず驚いたのはそ の研究環境のすばらしさであった．講座制は残っているも のの助教授の身分でも完全に独立した研究を行うことが認 められ, 若手研究者として願っても無い立場を授かること になった。 大型装置群の設置は既に有名となっているが, 単に設置されているだけでなく有能な専門職員による管理 も充分に行き届いている. 小型装置に関しても研究室間を はじめ, 大学間の貸し借りは非常にオープンである. しか も, 論文作成のための英文校正を行う外国人スタッフが配 置されていることも非常に有り難い.

JAIST の最近のニュースといえば，文部科学省の科学 技術振興調整費の中に新設された「若手研究者の自立的研 究環境整備促進」プログラムに採択され，この秋から，「ナ ノテク・材料研究者育成の人材システム」のテーマに取り 組んでいることである. 日本の大学教員等の人事では年功 主義的な色彩が強いケースが多くあり, その結果, 我が国 では独創性を基にして挑戦する意欲的な人材が育ちにくく， 革新的な成果が上がりにくい環境にあると指摘されている. そこで, 大学等にテニュア・トラックを導入し, 若手研究 者が斬新な発想を生かして自立的に教育研究に取り組める ポストや環境を整え, 教育研究の活性化を進めることが国 の科学技術政策の重要課題の 1 つとなっている。このこと を受けて設立された本プログラムは, 若手研究者が自立的 に生き生きと研究できる環境を整備する大学を国が支援す ることで, 大学の人事制度を革新するモデルとして位置づ

\footnotetext{
Kaneko, Tatsuo

北陸先端科学技術大学院大学 マテリアルサイエンス研究科

石川県能美市旭台 1-1（テ923-1211）

2006. 12.18 受理
}

金子 達 雄*

けられる。プログラムの遂行に当たり常勤の講師 7 人（女 性 1 人を含む日本人 4 人, ベトナム人 1 人, 韓国人 1 人, ドイツ人 1 人）の採用が決定し，多様性に富んだ人材が新 たな研究活動に挑戦し始めている.

\section{2. 研 究内容}

\section{1 概要}

金子研究室は昨年 5 月に誕生したばかりの新しい研究室 である. 5 月 1 日に設立後すぐに，微生物工学を専門とす る岡島研究員とともに研究室を整備しはじめ, 1 週間足ら ずで研究を開始できる状況にした，日増しに深刻化する環 境問題の解決を念頭に研究を進める以上は，基本的に時間 が無いという焦燥感にかられて, とにかく研究環境を整え ることに集中した，その後，JAIST に来て初めて立ち上 げた研究であるラン藻由来の多糖類の研究を計画し, 研究 員中心に実質的な研究をスタートさせた.この研究内容の 詳細は後に述べるが，9月に行われた IUPAC 主催の $1 \mathrm{st}$ GSC 会議で Poster Prize を受賞するなど国際的に認めら れる研究へと成長した. 著者自身も旧所属で行っていた環 境循環型エンジニアリングプラスチックの開発に関する研 究をさらに進め, 環境分解性と熱分解性に関する新しい知 見を得た ${ }^{2)}$. 7 月に入り 5 名の修士課程 1 年生が所属し, いよいよ本格的に研究を展開することとなった。研究の大 きな課題は「高分子ナノ構造制御を基盤に環境保全に役立 つ材料を創成すること」である．自然に存在する分子は複 雑な構造を持つことが多く, 石油化学産物として得られる 単純な構造の分子から天然分子を合成するには，多段階の 化学反応プロセスが要求されることが多い.この複雑な分 子の構造や形をありのまま受け入れ, そこからガイドされ るナノ構造を分子レベルから設計し, 新しいナノアーキテ クチャーを化学的・生物的に形作ることで環境調和型材料 を開発することを研究の基本的概念としている. 環境保護 に役立つ材料を作ることは「持続的に発展可能な社会」の 構築につながるだけではなく，人類を含むあらゆる動植物 をグローバルに守ることにもつながる最も意義深い研究課 題の一つと考えている. しかし, グローバルであるからこ そ潜む矛盾や困難が立ちはだかる極めて難しい課題とも考 えている. 従って, 様々な視点から客観的に研究を概観す る必要があり, 共同研究先も産学官と広範囲となり多種多 様な分野となった. 以下に研究内容の詳細を示す. 


\section{2 環境調和型高性能プラスチックの開発}

プラスチックの廃異物問題を解決するための, 有力な方 法の一つがポリ乳酸に代表される環境循環型高分子の利用 である. 環境循環型高分子は二酸化炭素を吸収する植物・ 微生物の代謝産物として得られることが望ましく，また廃 裹時には生態系の中にとけ込んでいく性質のものが理想的 である.ポリ乳酸はこの概念から創出された最もポピュ ラーかつ産業的に成功している高分子の一つであり, 医学 的分野からも注目される素晴らしい高分子である。そのほ かに, 数多くの環境循環型脂肪族系高分子が研究されてい るが，軟化温度が低いため基本的に使い捨ての分野のみに 応用される. そのため, これらは現在利用されているプラ スチックの 10〜20\%の代替にしかならないとされている ${ }^{3}$. 一般に耐熱性を向上させるためには，芳香環などの剛直な 成分を導入するのが常套手段である。これにより耐久性が 増す一方，環境に蓄積しやすいという問題点が生じてくる. しかし，植物中には，リグニンのような芳香族類の代謝産 物が意外と多く含まれている．リグニンは芳香環密度が高 いにも関わらず白色腐朽菌などにより環境中で分解される 特異な高分子である。一方，リグニンをそのまま材料化す る試みがあるが, 吸湿性・溶解性・加工性の問題から困難 とされている。そこで筆者は，リグニン前駆体またはリグ ニン生分解産物である芳香族系多官能性物質を高分子化す る手法を開発すれば, 高性能環境適応性高分子の新しい要 素技術として提案できると考えた。

本研究室では, 全芳香族のグリーンポリマーの作製を目 指して多官能性の桂皮酸類であるパラクマル酸とカフェ酸 を共重合したそその結果，これらの共重合性は著しく高く， 分子量 10 万を超えることが確認された。この高分子は液 晶性を保ち，高い配向度の樹脂を得ることが出来た。また， これらの剛性は高く, かつ全単位が桂皮酸構造を持ってい るので，光反応性も良好であった，外観は，褐色がかった クリーム色で配向による筋が見えるため，まさに木目のよ うな風合いであった（図 1)。種々の組成の共重合体ペレッ トの曲げ試験を行ったところ，ポリカーボネートを超える ヤング率 $(16 \mathrm{GPa})$ と破断強度 $(60 \mathrm{MPa})$ を示すことが わかった. 同時に, $169^{\circ} \mathrm{C}$ も高い軟化温度を示し, エン ジニアリングプラスチックとして十分に利用可能な性能を

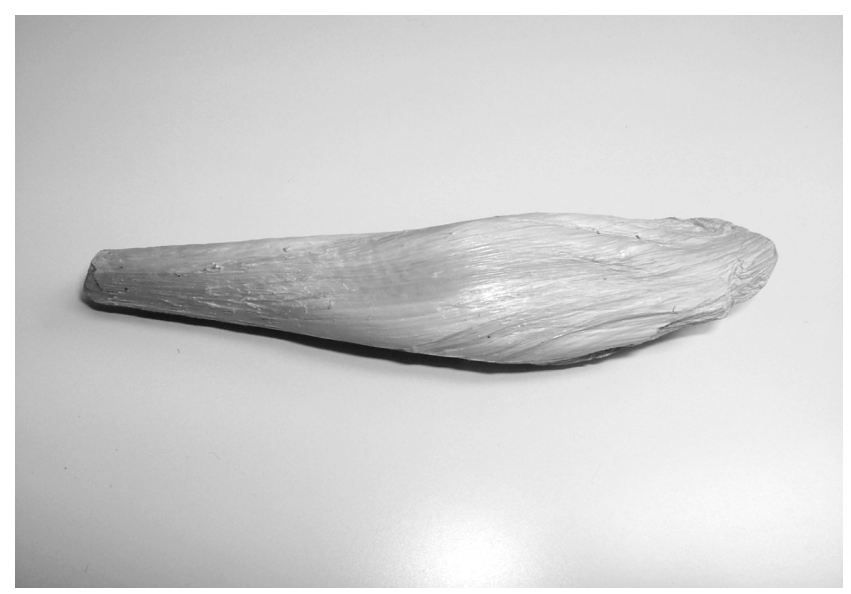

図 1 環境循環型エンプラの合成直後の写真
示した. 次に，細胞接着試験を行った。図 2 に細胞の顕微 鏡写真を示す．同図より，細胞が隙間なく伸展している様 子が観察され，これら共重合体においても，非毒性が保た れることがわかった．最後に，アルカリ温水中でペレット の加水分解加速試験を行った。 その結果，30日間の処理 により初期重量の数\%から $70 \%$ 重量減少することがわか り, 試料の変形も確認された。これにより, 桂皮酸類重合 体は加水分解性物質であることがわかった．また，阿蘇山 の斜面の土壤を用いて梁さ $10 \mathrm{~cm}$ の部分にこれら共重合 体の成形体を埋め, 環境分解性を調べた。その結果, 約半 年で最大 $10 \%$ の重量減少が見られ, 明らかな試料の変形 （図 3）抒よび力学強度の低減も確認できた。土中におけ る分解は, 菌・細菌類による分解である可能性が高く, か つ力学強度の低減により, 試料の内部にも分解が起こって いる可能性が示唆される。 このことは，上記微生物などか ら分泌される酵素などの作用によるものと考えられるため, 同試料は生分解性を示すプラスチックであると予想される.

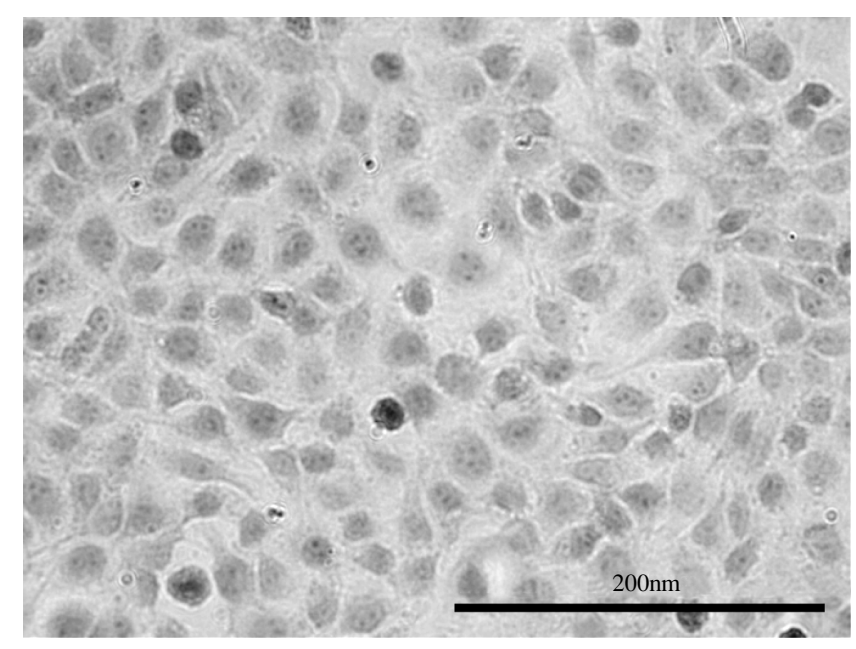

図 2 環境循環型エンプラ上で繊維芽細胞の伸展する様子

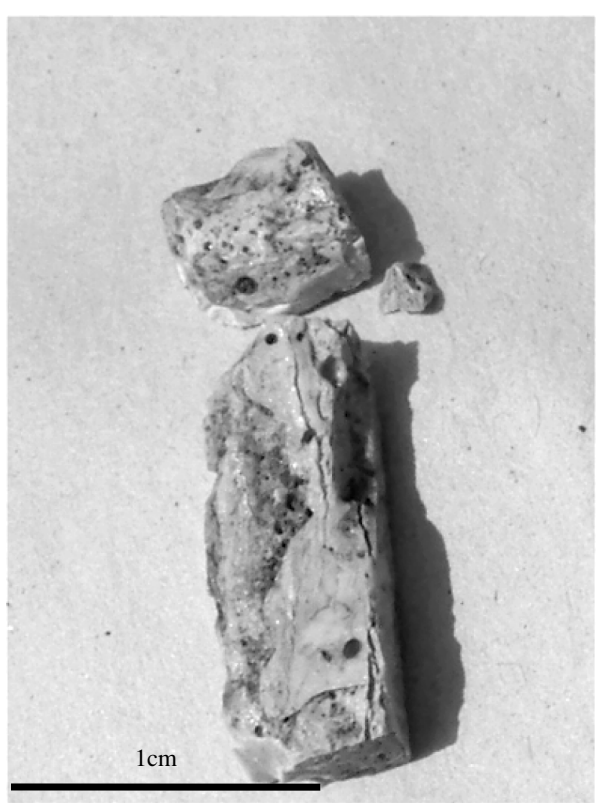

図 3 環境循環型エンプラの棒状成形体の土中分解試験片 （3 ケ月保持）の写真 


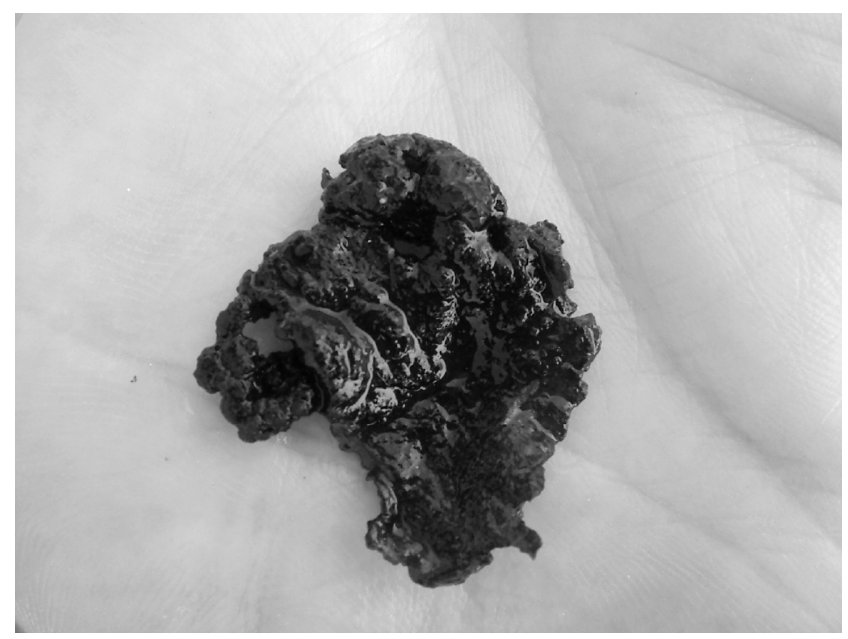

図 4 Aphanothece sacrum の概観

この手法は，元来悪玉と見られがちな芳香族資源を積極 的に有効利用し, 廃棄物問題解決に貢献できる新規な概念 をうち立てるものであり, 人間の生活に直接かかわる材料 を革新する役割を担うかもしれない. 現在, 反応性の低い 天然物を重合する方法の一つとしてエステル交換法の有効 性を見いだし, 高効率なエステル交換触媒と天然物由来の ナノハイブリッドの開発を進めている.

\section{3 光合成微生物を用いた材料開発}

原料獲得の段階で大気中の二酸化炭素濃度を積極的に下 げることは，単なる地上資源の利用にとどまらず，積極的 に地球温暖化を食い止める試みを行う意味で重要である. たとえば，空気中の二酸化炭素を固定化し光合成を行うラ ン藻は, 生物学上細菌類等と同じ原核生物に分類される. 従って, 必要な成育環境さえ整えば非常に高い増殖能力を 持つ特徴がある. しかも地球上至る所に様々な環境の下, 多様な種類のラン藻が豊富に生息している.よってこれら は一つのバイオマスと捉えることが出来る. しかし，これ らラン藻類の産出する天然高分子に着目し, それを材料化 する研究は未熟であるのが現状である. そこで本研究室で は, 現在まで殆ど学術的な研究が進んでいないラン藻種 Aphanothece sacrum（図 4）に注目し，これの生産する多 糖類を抽出して, それを機能性材料へと結びつける研究を 行っている. もともとラン藻類は大量に多糖類を細胞外に 分泌することで知られているが，この生物はその中でも特 に多量の多糖類を産出し, その重量は全重量に対し $80 \%$
以上にも及ぶものである. 抽出した多糖類は非常に高い硫 酸化度を持ち, 分子量も非常に高く極めて新規性の高い糖 鎖であることがわかっている. また，様々な金属イオンと 複合化し，ゲルを形成する能力を持っている. 金属イオン と多糖類のゲル化は海藻由来のアルギン酸で研究が進んで いるが，この抽出した新規多糖類はアルギン酸よりも低濃 度の金属イオンとゲル化し, ゲル形成を示す $\mathrm{pH}$ 域はアル ギン酸よりも著しく広かった。これらの性質を生かし高効 率に金属回収の出来る天然高分子由来材料の創製が可能と なる。

\section{3.おわりに}

以上のように，本研究室では天然分子の本来持つ構造や 形状をできるだけ維持させながら新しい物質系を作ること で，高性能・高機能環境循環型材料を作りあげることを目 的としている. 天然物を用いれば複雑な構造の構築を簡単 に行える可能性がある.これにより, 現用の環境蓄積型材 料の代替物の幅が大きく広がるものと考えている. それに 伴い, 二酸化炭素の発生量も抑制され, 今後の地球環境問 題の解決に大きく貢献することになる. 今後の課題の一つ として，植物や微生物から抽出される分子種を広げ，高性 能かつ汎用性の高いグリーンポリマーを効率よく開発する 方法論を提案することが挙げられる。これにより，あらゆ る地上資源を地球を守る材料に変換する夢を持ちつつ, 研 究に邁進する毎日である。この視点で, 産学連携を通し産 業の活性化を持続的に行っていければ幸甚である.

本学のホームページ

http : //www.jaist.ac.jp/index-j2.shtml

マテリアルサイエンス研究科のホームページ

http : //www.jaist.ac.jp/ms/index.html

金子研究室のホームページ

http : //www.jaist.ac.jp/ kaneko/

\section{参 考 文 献}

1 ）山口政之：成形加工，18，345(2006)

2 ) Kaneko, T., Tran, H. T., Shi, D. J. and Akashi, M. : Nature Mater, 5, 966 (2006)

3 ）土肥義治：理研ニュース，237(2001) http : //www.riken.jp/r-world/info/release/news/ 2001/mar/\#fro_01 